\title{
Effects of Using Practical Activities in Teaching Electronics Concept to Pre- service Teachers
}

\author{
Valentina Osei-Himah, Charles Agyei Amoah, Joseph Parker, \\ Science Department, Atebubu College of Education, Atebubu, \\ Science Department, OLA College of Education, Cape Coast \\ Science Department, Enchi College of Education, Enchi
}

\begin{abstract}
The study sought to use practical activities to teach basic electronics concepts to pre- service teachers from Atebubu College of Education in Ghana. Action research was used to carry out the investigation. A total of 200 pre-service teachers from first year were conveniently selected for the study. The instruments for the study were achievement test items and questionnaire. The result of the study indicated that the performance of the experimental group was significantly better than the pre-service teachers from the control group. It was recommended that the Principal and the Head of Science Department of Atebubu College of Education should organize workshops, seminars, and in-service training on the effective use of practical activity methods in teaching concept of electronics
\end{abstract}

Keywords: Basic electronics, Practical activities, Scientific knowledge

\section{Introduction}

There are many who are however of the view that, laboratory practical activities are often not easy to carry out. Some of the areas of concern raised by Knott and Mutanga (1995) are: severe time constraints and overloading of timetable leading to serious problems in meeting syllabus requirements in quality and quantity. In developing countries like Ghana, where curricula prescribe the use of practical activities, a number of constraints may prevent the implementation of practical activities in the laboratory. Commonly reported constraints include lack of equipment, large classes, overcrowded syllabi, and an examination system focused on factual recall while ignoring formal assessment of practical outcomes and the application of scientific reasoning to solve problems. For example, in Suva Fiji (north of New Zealand), Monk, Fairbrother and Dillon (1993) reported that teachers' curricula which make practical work mandatory have not been matched by equivalent changes in student evaluation procedures (Cook \& Taylor, 1994).

Apart from the constraints mentioned above, another factor is the role of practical activities perceived by teachers in developing countries including Ghana. In many cases, these activities are seen as having the role of confirming scientific knowledge as opposed to being exploratory in nature (Monk, Fairbrother \& Dillon, 1993). This role may in part be due to the difficulties in accessing information. In developing countries such as Ghana, access to libraries, ICT network, journals, and Textbooks for example is limited, making it difficult in teaching using practical activities. In addition to the previous constraints, further constraints on the implementation of practical activities in tropical countries such as in Fiji's situation is deterioration of equipment and materials caused by climate (Cook \& Taylor, 1994), a situation that is not far from occurring in the coastal parts of Ghana is worth considering. Compounding these problems are low maintenance standards for laboratory facilities and the lack of laboratory assistants requiring teachers to spend lengthy periods preparing experiments. Indeed, tutors may be found to lack the knowledge, skills and confidence necessary to perform routine maintenance tasks, and this restricted the amount of practical work that could be performed in a given period of time (Cook \& Taylor, 1994). This has necessitated the need to teach basic electronics using practical activities to find out whether it could improve the performance of students. 


\section{Statement of the Problem}

According to John, William, Sandra \& David (1996), students' ability to perform science process skills successfully during a practical lesson is dependent upon the students' previous experience, knowledge, and skills. At the College of Education, it is observed that basic electronics is not on the course outlines of both Integrated Science and Elective Physics but electronics has been added to the syllabus of Basic and Junior High Schools in Ghana since 2006. This has created a big problem for pre-service teachers who teach natural science topics including composition and types of transistors, use of transistors, converting electrical energy into light energy using simple electronic circuit during their internship. It is in the light of this that this research work was undertaken so that pre-service teachers, upon completion of their course of study, will not be found wanting as science teachers in Ghanaian classrooms.

\section{Purpose of the Study}

The study sought to use practical activities to teach basic electronics concepts to pre- service teachers from Atebubu College of Education.

\section{Research Question}

1. To what extent can practical activities influence pre-service teachers' understanding of basic electronics?

\section{Methodology}

The researcher adopted action research to carry out the investigation. The study focused on all preservice teachers from Atebubu College of Education. The college has three year groups of pre-service teachers; year one, two and three. Each year group consisted of five classes; A, B, C, D, and E with 40 preservice teachers in a class; constituting a total of 600 pre-service teachers in the college. The target population was all pre-service teachers from Atebubu College of Education and the accessible population for the study was the 2017/2018 first year pre-service teachers. This is because the first year pre-service teachers were more into learning science content as compared to the other two year groups. A total of 200 pre-service teachers from first year were conveniently selected for the study. Out of the 200 pre-service teachers, $65.0 \%$ were males and the other $35.0 \%$ were females. There were 100 pre-service teachers in the experimental and 100 in the control groups respectively. The sample was selected purposively. The preservice teachers were given the pre-test to respond and the mean scores were calculated for the two groups. The calculated mean scores for the experimental group was $\mathrm{M}=11.1(\mathrm{SD}=6.7)$ and that of control group was $\mathrm{M}=10.1(\mathrm{SD}=6.9)$. The placement of the pre-service teachers into the experimental and control groups was aided by the mean scores of the pre-service teachers in the pre-test. The pre-service teachers from groups with lower mean score (that is DBE 1A and D) were placed in the experimental group whereas the pre-service teachers with high mean score (that is DBE 1B and C) were placed in the control group. The instruments for the study were achievement test items and questionnaire. The research instruments were then pilot-tested with 30 pre-service teachers from Offinso College of Education in the Ashanti Region of Ghana. This is because the college was a co-educational institution and offered the same programs as the sampled center. The reliability of the achievement test was determined with the KR20 coefficient of reliability. This is because the test items were scored right or wrong. The KR20 reliability was calculated as 0.7 for both the pre-test and post-test. The Cronbach's alpha coefficient of reliability was used to establish the reliability of the questionnaire. It was established as 0.8.

\section{Results/Discussion}

Research question 1 sought to find out the pre-service teachers' understanding of basic electronics. To be able to achieve this, the pre-service teachers were initially given a pre-test to respond to. The results of the responses of the pre-service teachers from the pre-test are presented in Table 1. 
Table 1: Mean Scores of Pre-Service Teachers' Performance in the Pre-Test

\begin{tabular}{|c|c|c|c|c|}
\hline Group & $\mathrm{N}$ & $\bar{M}$ & $\mathrm{SD}$ & Max score \\
\hline $\begin{array}{l}\text { Control } \\
\text { Experimental }\end{array}$ & $\begin{array}{l}100 \\
100\end{array}$ & $\begin{array}{l}10.1 \\
11.1\end{array}$ & $\begin{array}{l}6.9 \\
6.7\end{array}$ & $\begin{array}{l}31 \\
27\end{array}$ \\
\hline
\end{tabular}

From Table 1, the results show that two-thirds of the pre-service teachers from the control group with a mean score of $10.1(\mathrm{SD}=6.9$, Max score $=31)$ scored marks ranging from 3.2 to 17.0 However, two-thirds of the pre-service teachers from the experimental group with a mean of 11.1 ( $\mathrm{SD}=6.7$, Max score $=27)$ scored marks ranging from 4.4 to 17.8. From Table 3, the findings show that the pre-service teachers show low performance in the pre-test and therefore seem to have difficulty in the concept of basic electronics. This could be inferred from the low mean scores for the pre-service teachers from the control and experimental groups.

A further look at the results in Table 1 shows that there was a difference between the performance of the pre-service teachers from the control and the experimental groups. This is because the mean score $(\mathrm{M}=$ $10.1, \mathrm{SD}=6.9)$ of the pre-service teachers from the control group seemed to be lower to that of the mean score $(M=11.1, S D=6.7)$ of the pre-service teachers from the experimental group. To determine whether the difference between the mean scores of the pre-service teachers from the two groups was significant as being investigated by the research hypothesis, the Mann-Whitney $U$ test was used. Table 2 presents the results of the Mann-Whitney U test analysis on the pre-service teachers' mean scores.

Table 2: Mann-Whitney U Test Analysis of Pre-Service Teachers' Performance in the Pre Test

\begin{tabular}{|l|l|l|l|l|}
\hline Group & \multicolumn{1}{|c|}{$\mathrm{N}$} & \multicolumn{1}{|c|}{ Mean rank } & \multicolumn{1}{c|}{$\mathrm{Z}$} & \multicolumn{1}{c|}{-value } \\
\hline Control & 100 & 94.4 & -1.490 & $0.136^{*}$ \\
Experimental & 100 & 106.6 & & \\
\hline
\end{tabular}

* Not significant, $\mathrm{p}>0.05$

The results from Table 2 show that there was no statistical significant difference between the mean scores of the pre-service teachers from the control group and the pre-service teachers from the experimental group. The reason being that the mean rank, 94.4 (Mann-Whitney $U=4393.0, Z=-1.490, p=0.136$ ) of the pre-service teachers from the control group was statistically not different from the mean rank, 106.6 of the pre-service teachers from the experimental group in the pre-test on basic electronics.

Research question 1 further sought to investigate the understanding of the pre-service teachers of basic electronics after having taking the teachers through the concept of basic electronic using the practical activity method. The pre-service teachers were made to respond to the post-test items on basic electronics. Table 3 presents the results of the mean scores of the pre-service teachers in the post-test on basic electronics.

Table 3: Mean Scores of Pre-Service Teachers' Performance in the Post-Test

\begin{tabular}{|l|l|l|l|l|}
\hline Group & $\mathrm{N}$ & $\mathrm{M}$ & SD & Max score \\
\hline Control & 100 & 11.5 & 7.2 & 33 \\
Experimental & 100 & 26.8 & 12.9 & 49 \\
\hline
\end{tabular}

The results from Table 3 show that two-thirds of the pre-service teachers with a low mean $(\mathrm{M}=11.5, \mathrm{SD}=$ 7.2, Max score $=33$ ) scored marks between 4.3 and 18.7 whereas two-thirds of the pre-service teachers with high mean $(\mathrm{M}=26.8, \mathrm{SD}=12.9$, Max score $=49)$ scored marks between 13.9 and 39.7. From Table 3, the findings show that the pre-service teachers from the experimental group performed creditably well compared to the pre-service teachers from the control group. Therefore the pre-service teachers from the experimental 
group's understanding of basic electronics could be said to have been enhanced by the use of the practical activity method.

From Table 3, the results further the show that the mean score $(\mathrm{M}=26.8, \mathrm{SD}=12.9$, Max score $=49)$ of the pre-service teachers from the experimental group was higher than that of the mean score $(\mathrm{M}=11.5, \mathrm{SD}=7.2$, Max score $=33$ ) of the pre-service teachers from the control group. To investigate further whether there was statistical significant difference between the mean scores of the pre-service teachers form the control and the experimental group, the Mann-Whitney $U$ test analysis was conducted. The Mann-Whitney $U$ test analysis results of the pre-service teachers' performance in the post-test are presented in Table 4.

\section{Table 4: Mann-Whitney U Test Analysis of Pre-Service Teachers' Performance in the Post-Test}

\begin{tabular}{|l|l|l|c|c|}
\hline Group & \multicolumn{1}{|c|}{$\mathrm{N}$} & \multicolumn{1}{|c|}{ Mean rank } & \multicolumn{1}{c|}{$\mathrm{Z}$} & $\mathrm{p}$-value \\
\hline $\begin{array}{l}\text { Control } \\
\text { Experimental }\end{array}$ & 100 & 66.5 & -8.319 & $0.000^{*}$ \\
\hline
\end{tabular}

* Significant, $\mathrm{p}<0.05$

From Table 4, the results show that there was statistical significant difference between the mean scores of the pre-service teachers from the control and the experimental groups. This is because the mean rank (Mean rank $=134.5$, Mann-Whitney $\mathrm{U}=1600.0, \mathrm{Z}=-8.319, \mathrm{p}=0.000$ ) of the pre-service teachers from the experimental group was higher to that of the mean rank, 66.5 of the pre-service teachers from the control group. The findings show that the pre-service teachers from the experimental group performed significantly better than the pre-service teachers from the control group. This could be attributed to the practical activities the pre-service teachers were introduced to, which has enhanced their understanding of the concept of basic electronics (Lunetta, 1998).

\section{Key Findings}

The following were the key findings of the study.

The understanding of pre-service teachers in basic electronics:

a. Was weak in the pre-test at the pre-intervention stage of the study. This is because the mean scores of the pre-service teachers from both the control and the experimental groups were very low.

b. Was significantly not different in the pre-test at the pre-intervention stage of the study. This is because the mean score of the pre-service teachers from the control group was statistically significantly not different from the mean score of the pre-service teachers from the experimental group in the pre-test.

c. The performance of the experimental group was high as such pre-service teachers obtained a high mean and maximum score in the post-test after the intervention. This is also further supported by the fact that two-thirds of the pre-service teachers from the experimental group fell within a large range of the mean score.

d. The performance of the experimental group was significantly better than the pre-service teachers from the control group. This is because the mean score of the pre-service teachers from the experimental group was statistically different from the mean score of the pre-service teachers from the control group.

\section{Conclusion}

The study sought to use practical activities to teach basic electronics concepts to pre- service teachers from Atebubu College of Education to improve their understanding. It was concluded that the performance of the experimental group was significantly better than the pre-service teachers from the control group after the intervention.

\section{Recommendations}

1. The Principal and the Head of Science Department of Atebubu College of Education should organize workshops, seminars, and in-service training on the effective use of practical activity methods in teaching concept of electronics. 
2. The GES together with MOE should furnish the Colleges of Education with the needed components of basic electronics as pre-service teachers perceived that by learning basic electronics they will be exposed to components such as diodes, resistors, and capacitors.

\section{References}

[1] Cook, A., \&Taylor, N. (1994). Robust adaptive process: The case for laboratory assistants in Fiji high school. Journal of Science and Mathematics Education inAsia, 17, 7-15.

[2] John W., Williams C.K., Sandra K.A.\& David C.E. (1996) Journal of Research in Science Teaching. The official Journal of the National Association for Research in Science Teaching.33 (7) New York

[3] Knott, M., \&Mutanga, P. (1995).Methods of teaching and learning. In B. Matiru, A., Mwangi,\&R., Schlette (Eds.), Teaching your best (pp.157-221). Bonn German Foundation for International Development (DSE).

[4] Lunetta, V. N. (1998). The school science laboratory: Historical perspective and centres for contemporary teaching. In P. Freshman (Ed.), Development and dilemma in science education, (pp.169-188).London:Falmer Press.

[5] Monk, M.J., Fairbrother, R.W., \& Dillon, J.S. (1993). Learning content through process: Practical strategies for science teachers in developing countries. Journal of Science and Mathematics Education in S.E.Asia, 16, 13-20. 